\title{
FREQUENCY OF SOME ACROPODIUM DISEASES IN DAIRY COWS IN SERBIA
}

\author{
MILOSAVLJEVIĆ P and SAVIĆ-STEVANOVIĆ VERA
}

University of Belgrade, Faculty of Veterinary Medicine, Serbia

(Received 6th September 2012)

The research included 520 dairy cows on 64 mini-farms in mountainous Serbian areas, with the goal to acquire an insight on acropodium diseases frequency in dairy cows, as well as distribution of hoof alterations. In $56.25 \%$ of farms, animals were kept tied in the stable, while $43.75 \%$ were grazing regularly or occasionally. Only $10.94 \%$ of farms were free of hoof acropodium alterations. Extremely bad hygienic conditions were noted in $18.75 \%$ of farms, where $74.01 \%$ of animals had acropodium lesions. Based on clinical analysis of 520 dairy cows, 388 of them were diagnosed with acropodium alternations: overgrown hooves (in $21.91 \%$ of animals), shoe-like hooves $(7.22 \%)$, scissors-like (17.27\%) and spiral hooves (8.76\%). Wounded acropodium skin was diagnosed in $1.8 \%$, interdigital phlegmon in $9.02 \%$, aseptic pododermatitis in $3.61 \%$, digital dermatitis in $4.89 \%$, interdigital dermatitis in $3.09 \%$, hoof ulcer in $3.35 \%$, interdigital blister in $4.89 \%$, hollow hoof wall in $6.18 \%$, horn wall rupture in $0.51 \%$, heel abscess in $3.09 \%$, tendovaginitis in $3.85 \%$ and crown joint displacement in $0.26 \%$ of animals. We found no pathological lesions of the acropodium in 132 animals (25.38\%).

Key words: acropodium, cow, diseases, Serbia

\section{INTRODUCTION}

Modern beef production, in addition to high-performance breeds, is based on the appropriate technology of breeding and exploitation. Many of the problems in this area of veterinary medicine and practice are caused by technological procedures in milk production. In such technologies, animals are frequently deprived of movement. They have been placed in an unnatural enviroment, conditions and microclimate, with altered nutrition. Today, there are three world's key health and welfare problems in dairy cattle (based on data from 2002), namely lameness, reproductive disorders and mastitis (Vermunt, 2004). Lameness in dairy cows, first mentioned in 1839, is now a first-class problem of the dairy industry. It influences impaired milk production, welfare and health of dairy cows and it is regarded as a disease with severe economical consequences. Experience has shown that in over $90 \%$ of cases the causes of lameness are due to various alternations of the acropodium, and in most cases of the hoof. 
Over the past 20 years, world experience showed that about $60 \%$ of cattle might have problems with lameness (for example, in England from 36 to 69\%, USA $31-46 \%$ ) in one year. Considering that in $90.76 \%$ of cases the lameness is caused by lesions of the hoof, about $80 \%$ of which are on the caudal extremities, of which 18.18 to $75 \%$ the lateral hoof was altered (Green, 2002). In Danmark in 2005 up to $37.5 \%$ of examined cows had some kind of hoof lesion. Eighty three percent of cows once in a lifetime have a problem with lameness, $15 \%$ two times and 1.5\% three times or more (Ballantine, 2002; Chaplin, 2000, Fitzgerand, 2000). Sixty nine percent of cows have one hoof lesion diagnosed, and $13.8 \%$ of cows have more than three different lesions and/or alterations. Best farms in EU countries reported lameness in $5.8 \%$ of animals and in extreme cases (UK) up to $50.3 \%$. Prevalence of lameness in cows that are in stables was at $25.5 \%$ level whereas in cows on pastures was 17.17\% (New Zeland) (Warnick, 2001, Westwood, 2001; 2003). In Germany, lameness was diagnosed in $25-58 \%$ of cows (Cook, 2002). According to FAO data for developed countries, total losses in cattle production are up to $15 \%$. In underdeveloped countries, total loss averages 30 $40 \%$. Economic loss per cow due to lameness is $250 £$ (UK), or $300 \$$ (U.S.) (Hernandez, 2001; 2002).

Economic loss, caused by acropodium pathology, could be divided into three categories: premature exclusion from production (according to some data, up to $40 \%$ of all losses in production is due to lameness; up to $85 \%$ of animals in a particular herd are excluded because of acropodium pathology); reduced production (over $20 \%$ losses in milk production, along with weight loss) and cost of treatment (usually account for over $10 \%$ of all economic losses in cattle production) (Vokey, 2002).

Until now, there were no published results regarding the frequency of acropodium pathology in dairy cows in Serbia. Hence, we did a research on over 500 cows to gain an insight into this problem in Serbia. As it was said the most significant indicators of acropodium disease are pathological changes on the hooves. One of the external risks of hoof damage is the floor surface where the cow is stationed. The concrete surface on which cows walk and stand has received a great deal of attention. When smooth, it is slippery making footing difficult, and when is rough enough to give a reasonable grip, it is very abrasive and causes damage to the horn. Rough concrete has been associated with higher levels of lameness than well-textured concrete (Dippel et al., 2009). Severe problems of excessive wear may arise on new concrete, which is often extremely abrasive. Also, compression of the sole corium is directly related to the amount of time that cows spend standing, in particular where the surface conditions are unyielding, as with concrete. Stall usage indices provide useful information about the time spent lying down in the stall (Whay et al., 2003). Recent studies emphasized factors that relate design of the stall and the time spent lying down, or in holding areas and parlors (Penev et al., 2009). These factors are very important because if conditions of cattle housing are inappropriate, it adds to the list of external risks of acropodium disease. 
Acta Veterinaria (Beograd), Vol. 63, No. 2-3, 247-254, 2013.

\section{MATERIAL AND METHODS}

A total of 520 dairy cows, both Simmental and Holstein-Friesian breeds were studied in mountainous parts of Serbia. Analysis included 64 mini-farms with a varied number of animals - from 5 to 30 , with an average of 8 animals per stable. Clinical examination started with the acquisition of the history of the disease regarding limping animals. Individual examination of postures and appearance of hooves of each animal in the stable followed. We also studied the cows when in motion: straight towards us, away from us, to the left, to the right and circular walk. After which the feet were examined in the parlor while the cows were standing to be milked. The heels were cleaned using a volume water hose and then followed status analysis and examination of possible alternations on the hooves. During examination, in each stable, we analyzed the conditions under which the animals are housed. The information collected on the farm was largely detailed. However, only limited information could actually be used in the analysis due to large variations in the collected data. Housing and management factors included in the analysis were: type and amount of bedding, hygienic condition of the floor and the cubicles, feeding routines, the size of the herd, foot bathing routines, trimming routines, and whether the cows were grazing or not.

\section{RESULTS}

Clinical examination was conducted on 520 animals, mostly Simmental breed, and some Holstein-Friesian breed. Analysis included 64 mini-farms with a varied number of animals - from 5 to 30 , with an average of 8 animals per stable. In 36 farms (56.25\%) animals were housed in stables and deprived of pasture. In 28 farms $(43.75 \%)$ animals were grazing regularly or occasionally. Only 7 farms (10.94\%) were free of acropodium alterations. Extremely bad hygienic conditions (dirt, moisture, bad flooring), animals kept stationary were noted in 12 farms (18.75\%). These farms housed a total of 127 animals, 94 (74.01\%) of which had acropodium lesions.

Based on the conducted analysis, we established that $132(25.38 \%)$ had no acropodium lesions, while 388 animals showed the following acropodium alterations:

\begin{tabular}{|c|l|c|c|}
\hline Num. & Illness & Number of cows & Percent of ill cows \\
\hline \hline 1 & Stable-overgrown hoof & 85 & 21.91 \\
\hline 2 & "Fairy slipper-like" hooves & 28 & 7.22 \\
\hline 3 & Scissors-like hooves & 67 & 17.27 \\
\hline 4 & Spiral hooves & 34 & 8.76 \\
\hline 5 & Injured and wounded acropodium skin & 7 & 1.80 \\
\hline 6 & Aseptic pododermatitis & 14 & 3.61 \\
\hline 7 & Interdigital phlegmon & 35 & 9.02 \\
\hline
\end{tabular}




\begin{tabular}{|c|l|c|c|}
\hline Num. & Illness & Number of cows & Percent of ill cows \\
\hline \hline 8 & Digital dermatitis & 19 & 4.89 \\
\hline 9 & Interdigital dermatitis & 12 & 3.09 \\
\hline 10 & Hoof ulcer & 13 & 3.35 \\
\hline 11 & Interdigital blister & 19 & 3.89 \\
\hline 12 & White line - hollow wall & 24 & 6.18 \\
\hline 13 & Ruptured horn wall & 2 & 0.51 \\
\hline 14 & Heel abscess & 12 & 3.09 \\
\hline 15 & Tendovaginitis & 15 & 3.85 \\
\hline 16 & Crown joint dislocation & 1 & 0.26 \\
\hline
\end{tabular}

Acquired data show the existence of 16 different acropodium alterations in 520 dairy cows. The only known lesion we did not encounter was horn erosion.

Due to inadequate keeping and care, 215 animals showed deformed hooves. This is $41.35 \%$ of all examined cows and $55.4 \%$ of cows with described pathology.

\section{DISCUSSION}

The frequency of certain acropodium lesions is well known and documented by numerous researches. It is interesting that this pathology varies from farm to farm and from country to country. English studies revealed that $27 \%$ of cows were diagnosed with hoof ulcer, $20 \%$ with a hollow wall and $16 \%$ with digital dermatitis. In Denmark, however, $79 \%$ of hoof illness was digital dermatitis, $3.7 \%$ hoof ulcer, $16.3 \%$ horn erosions, $1.3 \%$ hollow wall (O'Callaghan, 2002; Rajkondavar, 2002). In our research, we diagnosed as follows: $4.89 \%$ digital dermatitis, $3.35 \%$ hoof ulcer, $6.18 \%$ hollow wall. In other parts of the world such as Australia, the pathology is completely different: hollow wall is present in $34-39 \%$ of animals, horn erosion in $42 \%$, horn wall rupture in $17 \%$. These are traumatic alterations due to long-term exposure to hard and dry terrain (Gregory and Taylor, 2002; Sauter-Louis, 2004).

There is a growing awareness of the importance of investigation, diagnosis and control of herd lameness. As is the case with most production diseases, the cause of the problem is likely to be multi-factorial and often difficult to identify with total conviction, but sub-solar hemorrhaging, white line disease, and sole ulcers are primary indicators of a previous laminitis.

Pododermatitis (laminitis) is an inflamation of the hoof crown (corium) (Holah, 2000; Ossent, 2000; Spencer, 2001). We noted it as aseptic chronic dermatitis in $3.61 \%$ of animals.

Interdigital phlegmon is phlegmonous purulent - necrotic inflammation of the skin and subcutaneous tissue above the hoof interdigital space. As far as the location is concerned, it can be coronary, as well as pulvinal. It may be cutaneous, subcutaneous, tenedinal, bony or even articular. In over $75 \%$ of all cases, 
interdigital phlegmon is diagnosed on the hind limb (Lischer and Ossent, 2002). This disease is one of the most common in the pathology of the locomotor system, being both a health and economic issue. We diagnosed it in $9.02 \%$ of all examined animals. In $20 \%$ of cows it produced metastases in tarsal joints.

In recent years such "super panaritium" caused by Staphylococci only has been described. In such a case, there is destruction of the hoof crown in two days.

Digital dermatitis was first described in Italy (Mortellaro, 1974), in the United States in 1980, and in England in 1988. Today, digital dermatitis is considered one of the most frequent causes of lameness in the European Union (over $20 \%$ of all cases of lameness). As a consequence, there is a decrease in milk production and increase of the cost of treatment (114£ per animal in England). We diagnosed it in $4.89 \%$ of examined dairy cows. Usually, it is localized on the palmar surface of the hoof, in vicinity to the cutaneous-horn border. It begins as hyperaemia of the skin and wet eczema. Usually, lesions are circumscribed and concave. Then, papilomatus proliferation takes place, frequently surrounded by hyperkeratosis of the skin with raised hair. Etiologically the disease if multifactorial and depends on the environment (humidity, hygiene). However, the prime cause of the disease is microbial - presumably spirochetes Treponema (T. denticoma, $T$. pallidum, $T$. brennaborneze). These bacteria cause periodontal disease in humans. Often Campylobacter fecalis, as well as Clostridium spp. bacteria are present. Treponemas synthesize proteases that damage and dissolve the epithelium and aggregate on the skin, as well as in the skin of the digits. In order for the disease to occur, it is required for the skin of the interdigital space and crown, to be exposed to moisture for a prolonged period of time. Decaying organic material and lack of oxygen are predisposing factors (Murray, 1996). However, animal to animal transmission has not been proven yet. After therapy, more than $60 \%$ of animals were affected again in 7 to 15 weeks.

Interdigital dermatitis is an acute or chronic inflammation of the skin in the dorsal part of the plantar interdigital space. It is characterized by redness and serous exudation and erosions of the epidermis. In some cases, there is necrosis of the cutis. Since 2002 it is considered as a form of digital dermatitis. It occurs in damp and unsanitary housing conditions and in some herds may occur in up to $15 \%$ of animals, usually on the caudal extremities. The disease is caused by synergetic activity of Fusobacterium necrophorum and Dicherobacter nodosus. $D$. nodosus protease has a low proteolytic index that enables bacteria to penetrate. F. necrophoum penetrates the skin, as well. Both bacteria produce elastases that are able to damage the epithelium and cause inflammation.

Often, this condition is the first phase of interdigital phlegmon, hoof abscess or erosion of the horn.

Hoof ulcer - Rusterholcs ulcer of the hoof (Pododermatitis solearis circumscripta purulenta et necrotica chronica) is a chronic, as well as necrotic hoof corium inflammation. Inflammation is located on the interspace between the sole and the foot pad. It starts as a consequence of mechanical trauma and subsequent infection. Usually the disease occurs in old animals and on the hind limbs, on the outer hoof if the horn tissue is overgrown. In some herds the prevalence is 5 to 25 percent. In England, the prevalence is $27 \%$, and in Denmark 
it is $3.7 \%$ (Lischer, 2002). In our study it was diagnosed in $3.35 \%$ of examined animals.

Interdigital dermal hyperplasia or interdigital blister is an inflammatory, as well as hyperplasic formation of various size of the skin between the hooves. It is located on the dorsal side and in the middle of the interdigital space (Manske, 2002). We diagnosed it in $4.89 \%$ of studied cows, with $63.16 \%$ of cases on both caudal extremities.

In this study white line disease was diagnosed in $6.18 \%$ of dairy cows. In Australia, however, this number goes to up to $35 \%$ of cows. White line disease is a traumatic lesion of the hoof horn seen as a separation of the carrier edge (sole) in the area of the middle third of the white line. The most common is basically septic pododermatitis in the region of the white line (Marferison, 2002; Offer, 2003).

Rupture of the horn wall is represented by a disrupted continuity of the hoof wall and can be longitudinal or transverse. It occurs as a result of laminitis and long standing on hard floors. We diagnosed it in $0.51 \%$ of animals, while in Australia it is diagnosed in 17-22\% of cows (Jubb, Malmo, 1991; Malmo and Vermunt, 1999).

Heel abscess is a local and limited accumulation of pus in the fibrous tissue of the digital foot pad which with time results in destruction of the horn in the heel area. It is the result of interdigital phlegmon, purulent podotrochleitis and arthritis of the joint, horn erosions etc (O'Callaghan, 2003; Paulus and Nuss, 2002; Murray, 1996). We diagnosed it in $3.09 \%$ of dairy cows.

Since this research was conducted in mountainous parts of Serbia, different results can be expected in dairy cows located on flat terrains or river valleys, as well as in farm agglomerations.

Address for correspondence:

Dr Petar Milosavljevic, professor

Faculty of Veterinary Medicine

University of Belgrade

Bulevar oslobodjenja 18

11000 Belgrade, Serbia

\section{REFERENCES}

1. Ballantine $H T, 2002$, Effect of feeding complexed zinc, manganese, copper and cobalt to late gestation and lactating dairy cows on claw integrity, reproduction and lactation performance, Prof Anim Sci, 18, 211-8.

2. Chaplin SJ, 2000, A comparison of hoof lesions and behavior in pregnant and early lactation heifers at housing, Vet $J, 159,147-53$.

3. Collard BL, 2000, Relationships between energy balance and health traits of dairy cattle in early lactation, J Dairy Sci, 83, 2683-90.

4. Cook NB, 2000, The influence of barn designe on dairy cow hygiene, lameness and udder health, Proc Am Bovine Pract, 97-103.

5. Dippel S, Dolezal M, Brenninkmeyer C, Brinkmann J, March S, Knieri, U, Winckler C, 2009, Risk factors for lameness in cubical housed Austrian Simmental dairy cows, Prev Vet Med, 90, 10212.

6. Fitzgerald T, 2000, The influence of long-term supplementation with biotin on the prevention of lameness in pasture fed dairy cows, J Dairy Sci, 83, 338-44. 
7. Green $L E, 2002$, The impact of clinical lameness on the milk yield of dairy cows, J Dairy Sci, 85, 2250-6.

8. Gregory NG, Taylor OD, 2002, Dairy cow preference for a soft track surface, New Zeal Vet J, 52, 83-7.

9. Hedges J, 2001, A longitudinal field trial of the effect of biotin on lameness in dairy cows, J Dai Sci, 84, 1969-75.

10. Hernandez J, 2001, Effect of lameness on the calving-to-conception interval in dairy cows, JAVMA, 218, 1611-4.

11. Hernandez J, 2002, Effect of lameness on milk yield in dairy cows, JAVMA, 220, 640-4.

12. Higuchi $H$, Nagahata $H, 2001$, Relationship between serum biotin concentration and moisture content of the sole horn in cows with clinical laminitis or sound hooves, Vet Rec, 148, 209-10.

13. Holah $D E, 2000$, The histology and histopathology of the support structures in the laminated region of the bovine hoof in maiden heifers and around the time of first calving, Proc Soc Dis Rum Digit, 109-12.

14. Jubb TF, Malmo J, 1991, Lesions causing lameness requiring veterinary treatment in pasture- fed diary cows in East-Gippsland, Aust Vet J, 68, 21-4.

15. Laven RA, Hunt $H, 2002$, Evaluation of copper sulphate, formalin and peracetic acid in footbaths for the treatment of digital dermatitis in cattle, Vet Rec, 151, 144-6.

16. Lischer CJ, Ossent P, 2002, Pathogenesis of sole lesions attributed to laminitis in cattle. Proc Soc Lame Rumin, 82-9.

17. Lischer CJ, 2002a, Effect of therapeutic dietary biotin on the healing of uncomplicated sole ulcers in dairy cattle - a double blinded controlled study, Vet $J, 163,51-60$.

18. Lischer CJ, 2002b, Suspensory structures and supporting tissues of the third phalanx of cows and their relevance to the development of typical sole ulcers (Rusterholz ulcers), Vet Rec, 151, 6948.

19. Malmo J, Vermunt JJ, 1999, Lameness in dairy cattle - A review (part 2), J Aust Assoc Cattle Vet, 9 , 15-8.

20. Manske T, Hultgren J, Bergsten C, 2002, The effect of claw trimming on the hoof health of Swedish dairy cattle, Prev Vet Med, 54, 113-29.

21. Margerison JK, Winkler B, Stephens G, 2002, The effect of locomotion score and lameness and on dry matter intake, feeding and general behavior, Proc Soc Lame Rumin, 407-10.

22. Murray RD, 1996, Epidemiology of lameness in dairy cattle: descriptions and analysis of foot lesions, Vet Rec, 138, 586-91.

23. Melendez PJ, 2002, Relationship between lameness, ovarian cysts and fertility in Holstein cows, Proc Soc Lame Rumin, 339-42.

24. Nocek JE, 2000, Digital characteristics in commercial dairy herds fed metal-specific amino-acid complex, J Dairy Sci, 83, 1553-9.

25. O'Callaghan $K, 2002$, Lameness and associated pain in cattle - challenging traditional perceptions, In Practice, 24, 212-19.

26. O'Callaghan KA, Cripps PJ, Downham DY, Murray RD, 2003, Subjective and objective assessment of pain and discomfort due to lameness in dairy cattle, Anim Welf, 12, 605-10.

27. Offer J, 2003, Effect of forage type on claw horn lesion development in dairy heifers, Vet J, 165, 2217.

28. Ossent P, 2000, Bovine laminitis: the lesions and theories on their pathogenesis, Proc Soc Dis Rum Digit, 31-3.

29. Paulus N, Nuss K, 2002, Claw measures at defined sole thickness, Proc Soc Lame Rumin, 428-30.

30. Penev T, Mitev J, lliev A, Borisov I, Miteva T, Gergovska Z et al., 2012, Hygienic and technological conditions favouring lameness in dairy cows, Rev Med Vet, 163, 499-504.

31. Rajkondawar $\mathrm{P}, 2002$, A system for identifying lameness in dairy cattle, App/ Eng Agric, 18, 87-96.

32. Somers JG, 2003, Prevalence of claw disorders in Dutch dairy cows exposed to several floor systems, J Dairy Sci, 86, 2082-93.

33. Spencer E, 2001, Heat stress and lameness, New Hoof Trimm Assoc, 8.

34. Tarlton JF, Webster AJF, 2003, Biochemical, histopathological and biomechanical mechanisms of lameness associated with first calving, Cattle Pract, 11, 81-7. 
35. Tranter WP, Morris RS, 1991, A case study of lameness in three dairy herds, New Zeal Vet J, 39, 8896.

36. Vermunt JJ, 2004, Herd Lameness-A review, Major Causal Factors and Guidelines for Prevention and Control, Proc Soc Lame Rumin, 2004.

37. Vokey FJ, 2002, Effects of alley and stall surfaces in indices of claw and leg health in dairy cattle housed in a firestall barn, J Dairy Sci, 84, 2686-99.

38. Warnick $L D, 2001$, The effect of lameness on milk production in dairy cows, J Dairy Sci, 84, 198897.

39. Westwood CT, Lean IJ, 2001, Nutrition and lameness in pasture-fed dairy cattle, Proc New Zeal Anim Prod, 61, 128-34.

40. Westwood CT, 2003, Review of the relationship between nutrition and lameness in pasture-fed dairy cattle, New Zeal Vet J, 51, 208-18.

41. Whay HR, Main DC, Green LE, Webster AJ, 2003, Assessment of the welfare of dairy cattle using animal-based measurements: Direct observations and investigation of farm records, Vet Rec, $153,197-202$.

\title{
UČESTALOST POJEDINIH OBOLJENJA AKROPODIJUMA MUZNIH KRAVA U SRBIJI
}

\author{
MILOSAVLJEVIĆ P i SAVIĆ-STEVANOVIĆ VERA
}

\begin{abstract}
SADRŽAJ
$\mathrm{U}$ ovom istraživanju klinički je ispitano 520 grla na 64 mini farme u brdskoplaninskom području Srbije, sa ciljem da se dobije uvid u učestalost oboljenja akropodijuma muznih krava kao i zastupljenost pojedinih alteracija. U 56,25\% domaćinstava grla su bila stalno vezana a u $43,75 \%$ se redovno ili povremeno dopušta puštanje na pašu. Na samo 10,94\% farmi nisu ustanovljene nikakve alteracije akropodijuma. Izrazito loši higijenski uslovi su evidentirani u $18,75 \%$ domaćinstava I tu je 74,01\% imalo neku leziju akropodijuma. Na osnovu kliničke analize svih 520 muznih krava , kod 388 su ustanovljene sledeće alteracije akropodijuma: prerasle papke u $21,91 \%$ slučajeva, papučaste u $7,22 \%$, makazaste u $17,27 \%$ a spiralne u $8,76 \%$ grla. Rane na koži akropodijuma su evidentirane u $1,80 \%$, aseptični pododermatitis u $3,61 \%$, interdigitalna flegmona u $9,02 \%$, digitalni dermatitis u 4,89\%, interdigitalni dermatitis u 3,09\%, čir papka u 3,3,35\%, međupupčani žulj u 4,89\% slučajeva, šuplji zid u 6,18\% slučajeva, prsnuće zida rožine u $0,51 \%$, apsces pete u $3,09 \%$, tendovaginitis u 3,85\% i iščašenje krunskog zgloba u 0,26\% grla. Bez patoloških lezija na akropodijumu je bilo 132 životinje $(25,38 \%)$.
\end{abstract}

